\title{
Studi Implementasi Reparasi Kapal Berbasis Keandalan untuk Galangan Kapal
}

\author{
Ahmad Muhtadi, Triwilaswandio Wuruk Pribadi, dan Imam Baihaqi. \\ Jurusan Teknik Perkapalan, Fakultas Teknologi Kelautan, Institut Teknologi Sepuluh Nopember (ITS) \\ Jl. Arief Rahman Hakim, Surabaya 60111 Indonesia \\ e-mail: triwilas@na.its.ac.id
}

\begin{abstract}
Abstrak - Tujuan dari tugas akhir ini adalah untuk memperbaiki kondisi keandalan pada perbaikan kapal di galangan kapal saat ini dengan melakukan pendekatan implementasi keandalan. Dengan pendekatan ini peneliti melakukan penyelesaian masalah ketidakandalan dan implementasi keandalan pada reparasi/perbaikan kapal di galangan kapal. Pertama, dilakukan kunjungan ke galangan untuk mencari kondisi keandalan pada proses dan hasil perbaikan kapal. Kegiatan yang dilakukan berupa pengambilan data docking repair list kapal dan diskusi tentang aktifitas perbaikan kapal yang dilakukan di galangan kapal. Kedua, data yang didapat kemudian diolah berdasarkan teori Reliability Analysis dan teknik Root Cause Analysis. Ketiga, hasil dari pengolahan data dianalisa untuk mendapatkan model identifikasi ketidakandalan pada perbaikan kapal. Model ini digunakan sebagai landasan untuk melakukan mitigasi dan implementasi keandalan pada perbaikan kapal. Setelah mitigasi dan implementasi dilakukan, diciptakanlah sebuah bagan alur pengimplementasian beserta target dan strategi implementasi pada perbaikan kapal. Hasil yang didapatkan dari tugas akhir ini berupa kerangka kerja peningkatan keandalan pada galangan kapal yang berisi identifikasi faktor SDM, Material, Sarana \& Prasarana, SOP, Kondisi Lapangan, dan desain.
\end{abstract}

Kata Kunci - Galangan Kapal, Keandalan, Perbaikan Kapal, Studi Implementasi.

\section{PENDAHULUAN}

$\mathrm{K}$ APAL sebagai sarana transportasi lintas air digunakan dalam proses penyebaran logistik impor dan ekspor antar pulau nasional dan internasional. Kapal digunakan secara terus menerus (24H/7D). Kondisi kapal yang baik adalah kewajiban dari setiap pemilik kapal dan pengguna kapal. Maintenance dan repair yang baik akan memberikan keuntungan ekonomis dan teknis terhadap kapal. Maintenance dan repair secara berkala di dok atau lebih dikenal dengan docking kapal dilakukan setiap dua tahun sekali. Hal ini sudah diatur oleh IACS tentang kewajiban dry docking untuk merchant ship.

Proses perbaikan (docking) kapal baiknya selalu dilakukan tepat waktu dan tidak ditunda-tunda. Proses perbaikan kapal dilakukan di galangan kapal yang berkapasitas untuk melakukan perbaikan. Proses perbaikan kapal yang baik tentunya dilakukan oleh galangan dengan manajemen pekerjaan yang baik. Didukung oleh Quality Control dan Quality Assurance yang baik dan dipatuhi oleh seluruh sumber daya manusianya.
Ketika semua yang dikerjakan sudah baik, namun masih sering terjadi kerusakan sebelum waktunya, hal ini dapat menyebabkan kerugian bagi pemilik kapal secara ekonomis. Kejadian seperti ini seharus tidak perlu dialami oleh pemilik kapal yang sudah membayar mahal kegiatan docking kapal. Hal-hal seperti inilah yang dijadikan bahasan dalam pembuatan Tugas Akhir ini.

Tentunya ada banyak faktor yang menyebabkan kerusakan komponen sebelum waktunya. Keandalan termasuk dalam faktor yang sering dilalaikan dalam perbaikan kapal. Kualitas yang baik belum tentu mencerminkan keandalan yang baik karena hal tersebut tidak memperhitungkan faktor waktu. Hal ini dikarenakan keandalan adalah kualitas dari waktu ke waktu. ${ }^{[1]}$

Untuk permasalahan komponen hasil perbaikan yang rusak sebelum waktunya, implementasi keandalan dapat menjadi solusinya. Penulis melihat keandalan jika diimplementasikan ke perbaikan kapal dapat menyelesaikan masalah ketidakandalan pada hasil dan proses perbaikan kapal.

Masalah yang akan dilakukan penelitian dalam tugas akhir ini adalah (1) Bagaimana kondisi aktivitas perbaikan kapal, khususnya yang berhubungan dengan keandalan di galangan kapal, (2) Bagaimana kondisi tersebut dapat diperbaiki dengan pendekatan keandalan, (3) Bagaimana pendekatan terebut dapat diimplementasi pada perbaikan kapal di galangan. 


\section{METODOLOGI}

\section{A. Alur Penelitian}

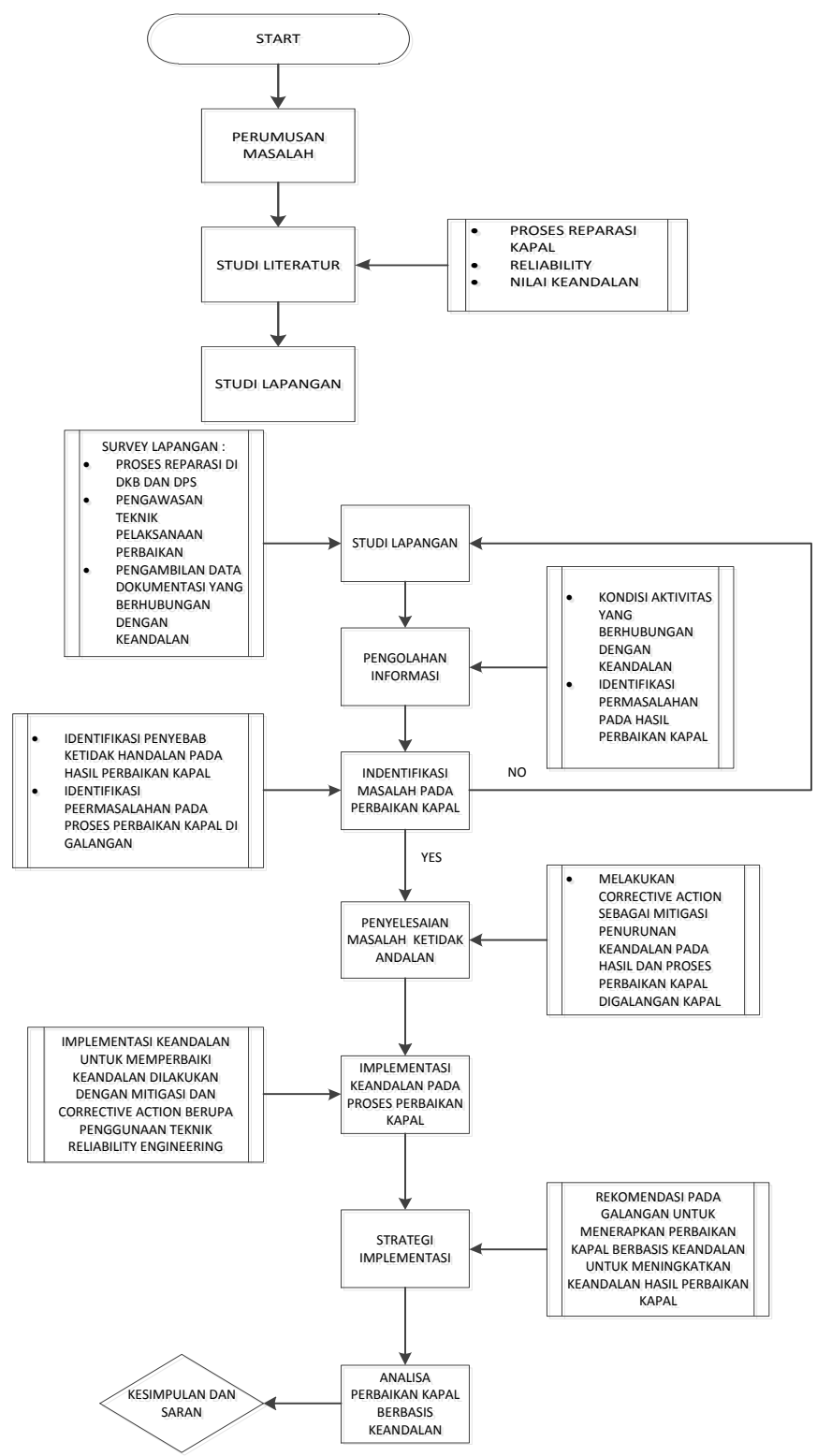

Gambar 1 Diagram Alur Penelitian

\section{B. Proses Penyelesaian Masalah}

Untuk menyelesaikan penelitian tentang analisa kegagalan tentang suatu hal, dibutuhkan dasar pengambilan keputusan atau setidaknya rangka pengerjaan sehingga dapat diperoleh sebuah kesimpulan. Oleh karena itu dibutuhkan suatu model garis besar penyelesaian masalah yang ilmiah. James J. Scutti dalam buku Introduction to failure Analysis and Prevention mendefinisikan sebuah model proses penyelesaian masalah yang diadaptasi dari beberapa problem solving model yang ada. Model yang ia keluarkan mempunyai bentuk grafik melingkar yang mengindikasikan bahwa proses terus menerus dilakukan. ${ }^{[2]}$

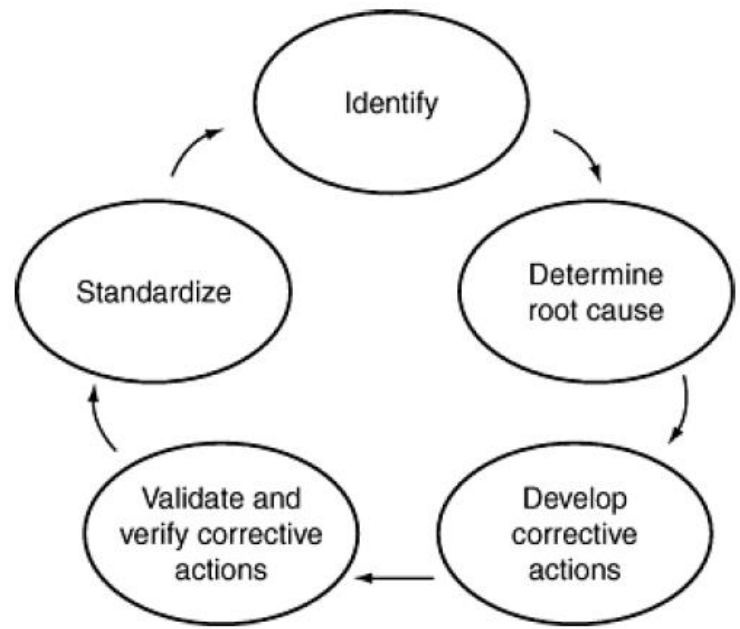

Gambar 2 Model Umum Penyelesaian Masalah Ketidakandalan ${ }^{[3]}$

Langkah-langkah dalam model tersebut menunjukkan proses yang terjadi dalam penyelesaian masalah yang terdiri dari:

1. Identify (Identifikasi Masalah)

Mendefinisikan permasalahan yang terjadi pada sistem dan akibat yang terjadi pada sistem tersebut lalu melakukan pencarian data untuk mendukung pengukuran masalah.

2. Determine Root Cause (Mencari akar Permasalahan)

Melakukan analisa untuk mencari akar dari permasalahan tersebut.

3. Develop Corrective Actions (Kembangkan Solusi Permasalahan)

Merancang solusi yang mungkin untuk diterapkan untuk mencegah terjadinya masalah, membuat solusi alternatif dan mengembangkan rencana implementasi.

4. Validate and Verify Corrective Actions (Mengesahkan dan Memerikasi Corrective Action)

Melakukan studi tentang efek yang terjadi pada sistem tersebut setelah diterapkannya solusi terhadap masalah tersebut. Validasi solusi tersebut dan pemeriksaan apakah masalah dari sistem tersebut telah selesai.

5. Standardize (standarisasi)

Masukkan langkah penyelesaian masalah tersebut ke dalam sitem organisasi yang bersangkutan. Setelah itu dilakukan pengawasan untuk melihan ke efektifannya.

\section{STUDI PERBAIKAN KAPAL BERBASIS KEANDALAN}

\section{A. Kerangka Kerja Perbaikan Kapal}

Framework atau kerangka kerja, digunakan sebagai penyedia informasi umum tentang perbaikan kapal. Nantinya informasi ini akan digunakan lebih lanjut dalam memprediksi penyebab ketidakandalan proses dan komponen dan hasil reparasi kapal. Identifikasi penyebab kegagalan komponen nantinya akan disediakan dalam bentuk daftar kegagalan.

\section{B. Root Cause Analysis}

Analisa kegagalan dan Root Cause Analysis ditunjukan untuk mengetahui penyebab terjadinya kerusakan yang spesifik dari peralatan, perlengkapan, dan instalasi pabrik serta untuk menentuka tindakan pencegahan agar kerusakan tidak terulang. 
Untuk penelitian ini, analisa keandalan lebih difokuskan ke penyebab terjadinya kegagalan atau ketidak andalahan dari komponen kapal hasil perbaikan kapal.

\section{Analisa Hasil RCA}

Dari hasil RCA komponen perbaikan kapal, ditemukan bahwa:

Tabel 1 Hasil analisa RCA

\begin{tabular}{|l|r|}
\hline \multicolumn{2}{|c|}{ Analisa Penyebab kegagalan } \\
\hline \multicolumn{2}{|c|}{ Komponen kapal } \\
\hline Total & 392 \\
\hline SDM & 119 \\
\hline Sarana Prasarana & 105 \\
\hline Material & 130 \\
\hline Planning & 83 \\
\hline External Factor & 45 \\
\hline
\end{tabular}

\section{Model Pengecekan Ketidakandalan perbaikan kapal}

Tahap awal dari pendekatan reliability analysis adalah dengan mengidentifikasi permasalahan pada objek yang di teliti. Pada penelitian ini objeknya adalah perbaikan kapal. oleh karena itu dipakailah sebuah model pengecekan yang dapat digunakan untuk mengidentifikasi permasalah pada perbaikan kapal. Model identifikasi akan dijabarkan pada subbab selanjutnya

\section{E. Model Identifikasi Permasalahan pada Perbaikan Kapal beserta Mitigasi dan Corrective Action}

\section{1) Pengecekan Berita Acara Kerusakan Kapal}

Pada awal indetifikasi permasalahan keandalan pada perbaikan kapal, ada tahap penting sebelum melakukan identifikasi pada galangan kapal. Tahap tersebut adalah tahap analisa laporan kerusakan kapal yang dikeluarkan oleh owner kapal. tahapan ini dilakukan untuk melakukan validasi apakah kerusakan yang terjadi karena kesalahan galangan dalam perbaikan kapal atau karena kesalahan dalam operasi kapal

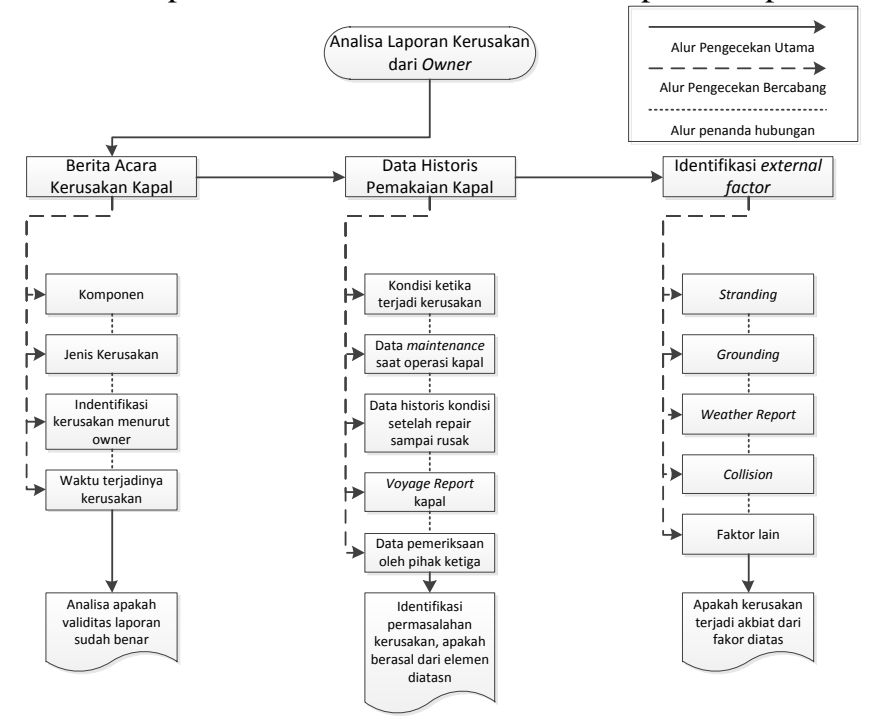

Gambar 3 Pemeriksaan Berita Acara Kerusakan Kapal

Bagan diatas menjelaskan tentang alur pemeriksaan dari berita acara kerusakan. Alur pertama pemeriksaan berupa validasi laporan kerusakan yang dikeluarkan oleh owner. Alur kedua adalah pemeriksaan data historis operasi kapal setelah perbaikan kapal terakhir dilakukan. Alur ketiga adalah pemeriksaan faktor eksternal yang dapat menyebabkan kerusakan pada perbaikan kapal. Apabila semua elemen lolos, baru identifikasi kerusakan dilanjutkan ke proses perbaikan kapal.

2) $\mathrm{SDM}$

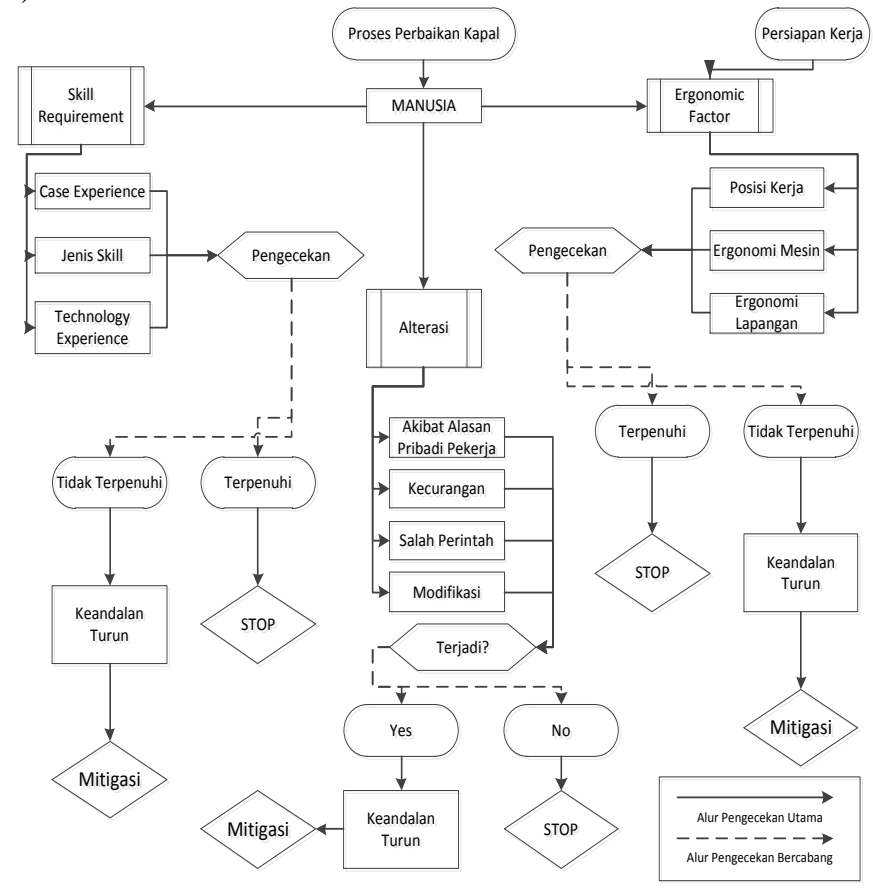

Gambar 4 Flowchart Identifikasi dan Mitigasi SDM

Gambar 4 menunjukkan alur identifikasi ketidakandalan yang bersumber pada elemen SDM di galangan kapal. rekomendasi corrective action dan mitigasinya adalah:

- Memperbaiki kualitas pekerjanya dengan tidak memakai pekerja tanpa experience karena ada perbedaan 3\% terhadap kemungkinan gagalnya suatu barang.

- Faktor Lingkungan kerja dari galangan harus ditingkatkan. Untuk kondisi lingkungan galangan harus dilakukan penelitian Ergonomis dalam sebuah pengerjaan perbaikan kapal. Faktor ergonomis yang saya pakai dalam penelitian ini saya ambil dari hasil wawancara dan pengamatan langsung dari galangan DPS.

- Faktor alterasi oleh pekerja. Faktor ini dapat diantisipasi dengan controlling yang baik oleh galangan yaitu dengan melakukan controlling process step by step. Walaupun menambah jam kerja dari supervisor/mandor. Tapi penambahan jam kerja tadi menyebabkan failure rate dari hasil pekerjaan repair menurun.

3) Material

Alur identifikasi permasalahan keandalan pada perbaikan kapal di galangan kapal dilakukan berdasarkan Gambar.5. Mitigasi dan corrective action nya adalah:

- Penyimpanan material harus dilakukan dengan benar.

- Proses Preparation material harus dilakukan step by step dengan benar.

- Proses perencanaan perbaikan kapal harus dilakukan perencanaan keandalan untuk melihat umur material, 
sehingga keandalan dari material dapat diketahui lebih awal.

- Pengawasan penggunaan material harus lebih diawasi oleh supervisor sehingga tidak ada kecurangan yang dapat dilakukan. Atau setidaknya kesempatan untuk menggunakan material yang bad quality dan underspec lebih kecil.

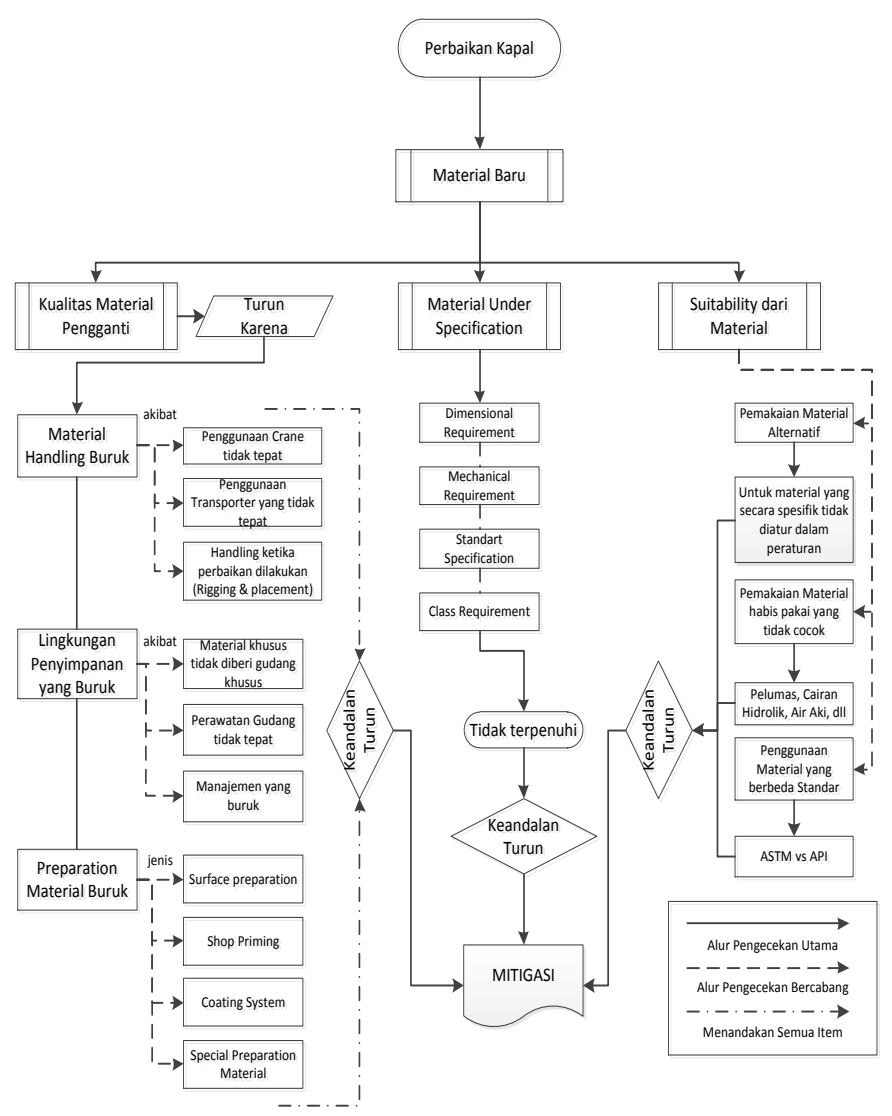

Gambar 5 Flowchart Identifikasi dan Mitigasi Material

4) Sarana \& Prasarana

Alur identifikasi masalah pada sarana dan prasarana dijabarkan pada Gambar 6. Mitigasi dan corrective action nya adalah;

- Dengan selalu menggunakan mesin dan peralatan yang memang dibutuhkan oleh proses tersebut.

- Jika memang tidak ditemukan peralatan yang memenuhi requirement maka dilakukanlah perubahan perencanaan pelaksanaan pekerjaan. Dilakukanlah perubahan parameter mesin yang digunakan. Kemudian analisa apakah pekerjaan tersebut masih dapat dilakukan tanpa merubah kualitas hasil perbaikan apa tidak.

- Selalu rajin melakukan perawatan untuk memelihara keandalan dari mesin. Perawatan dilakukan secara tahunan atau bulanan tergantung dari intensitas penggunaan mesin tersebut.

- Lakukan kalibrasi untuk mengecek akurasi dan pengecekan kondisi mesin untuk melihat apakah ada kerusakan yang terjadi pada mesin sehingga kerusakan tidak merambat ke hasil perbaikan kapal.
- Selalu memastikan bahwa pengguna mesin telah mengerti cara menggunakan mesin tersebut.

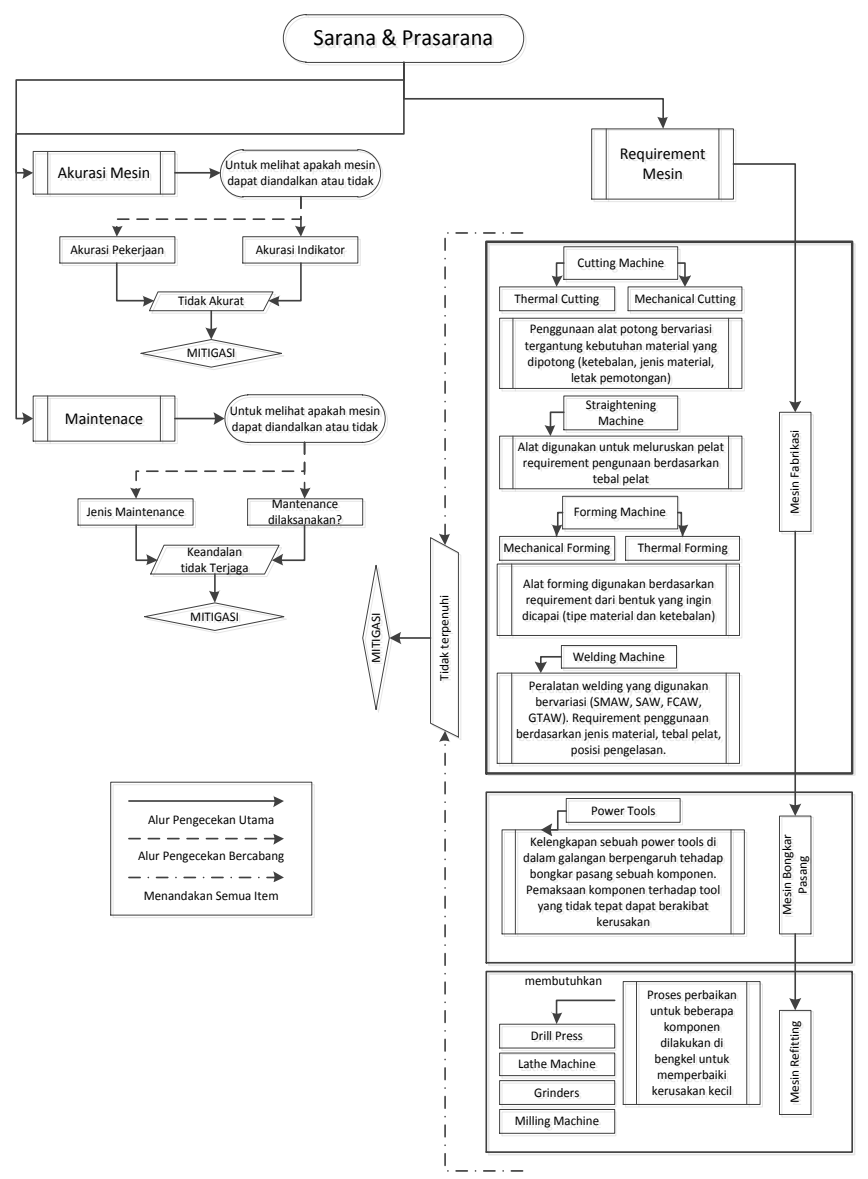

Gambar 6 Flowchart Identifikasi dan Mitigasi Sarana Prasarana 
5) Persiapan/Planning

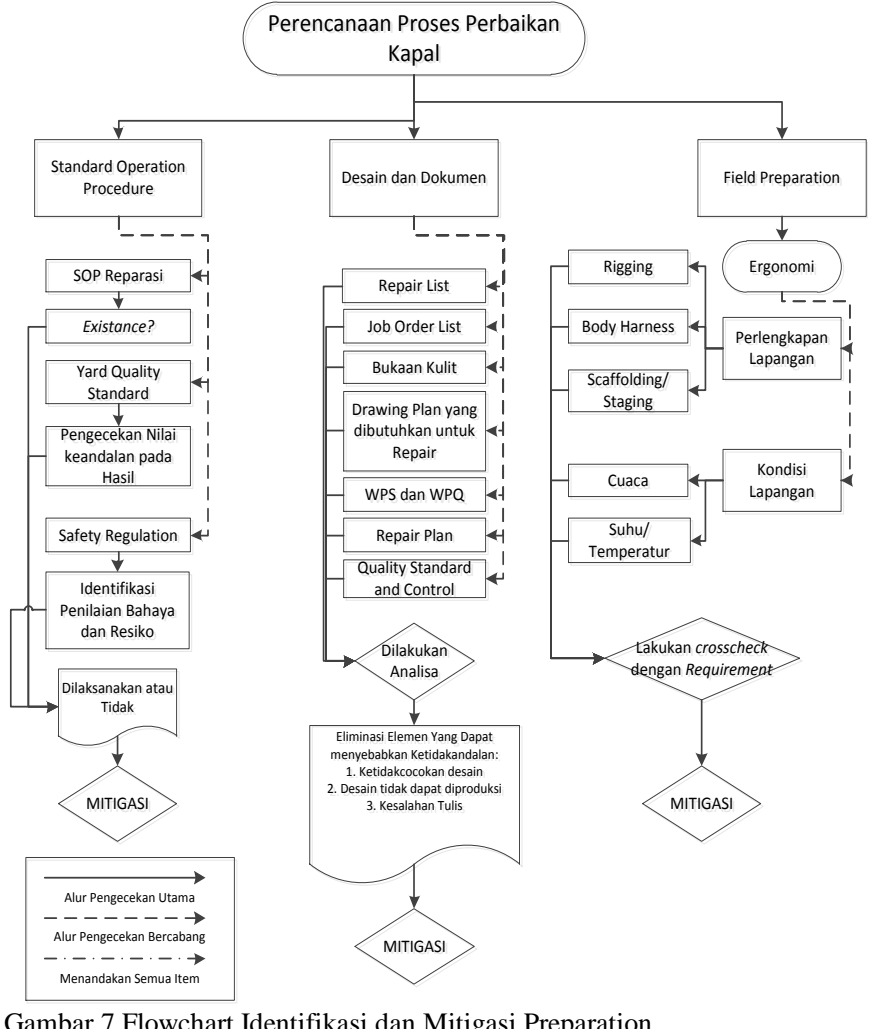

Gambar 7 Flowchart Identifikasi dan Mitigasi Preparation

Alur gambar 7 mejelaskan identifikasi permasalahan pada tahap preparation di galangan kapal. Sehingga Corrective Action nya adalah;

- Dengan melakukan proses desain berbasis keadalan. Adalah proses desain suatu komponen dengan mengikuti kaidah design for reliability. Dengan melakukan hal tersebut, maka komponen dan proses perbaikan kapal semakin sering dilakukan semakin baik.

- Melengkapi SOP dari galangan sehingga semua proses perbaikan kapal diatur dalam peraturan galangan.

- Selalu mempersiapkan lingkungan kerja yang baik sehingga nilai ergonomic dari SDM dapat terpenuhi.

\section{STUDI IMPLEMENTASI PERBAIKAN KAPAL BERBASI KEANDALAN}

\section{A. Implementasi dan Target keandalan di Galangan Kapal}

Implementasi keandalan di galangan kapal dapat dilakukan dengan beberapa macam pendekatan. Sebagai contoh, penerapan keandalan dalam hal operasi kapal dapat dilakukan dengan RCM. Bahkan sudah ada sebuah guidance dari ABS tentang penerapan Reliability Based Maintenance di Kapal. RCM membahas tentang memaksimalkan maintenance dengan menggunakan keandalan sebagai basis pengambilan keputusan untuk melakukan maintenance. Dalam penelitian ini kita mencoba mendefinisikan Reliability Based Ship Repair atau Perbaikan Kapal berbasis Keandalan.

Setelah diketahui elemen mana yang perlu dilakukan pengembangan untuk diterapkan keandalan sehingga kualitas perbaikan kapal di galangan secara umum, meningkat. Dilakukan rekomendasi bagaimana meningkatkan keandalan dari perbaikan kapal dengan melakukan teknik-teknik keandalan pada perbaikan kapal. Teknik-teknik keandalan sendiri banyak jenisnya, namun tidak semua teknik dan tools keandalan dapat diterapkan ke perbaikan kapal. Semua teknik yang dijelaskan dalan Gambar 8 adalah hasil dari melihat tools dan teknik keandalan yang dijabarkan dalam sebuah pelatihan yang memfokuskan sebuah organisasi untuk mengimplementasikan keandalan. ${ }^{[4]}$

\section{B. Strategi Implementasi}

Strategi adalah rencana yang cermat mengenai kegiatan untuk mencapai sasaran khusus (Kamus Besar Bahasa Indonesia). Dengan kata lain strategi adalah cara dan teknis yang dirancang untuk memastikan pencapaian pada sebuah tujuan. Dalam penelitian ini tujuan yang ingin dicapai adalah meningkatnya keandalan pada perbaikan kapal di galangan kapal. ${ }^{[5]}$

Hal yang dibahas dalam setiap sub-bab strategi implementasi pada gamabr 9 adalah ide bagaimana caranya agar keandalan dapat diimplementasikan dalam perbaikan kapal. Sebagai galangan kapal, galangan harus melakukan apa untuk mengimplementasikan keandalan.

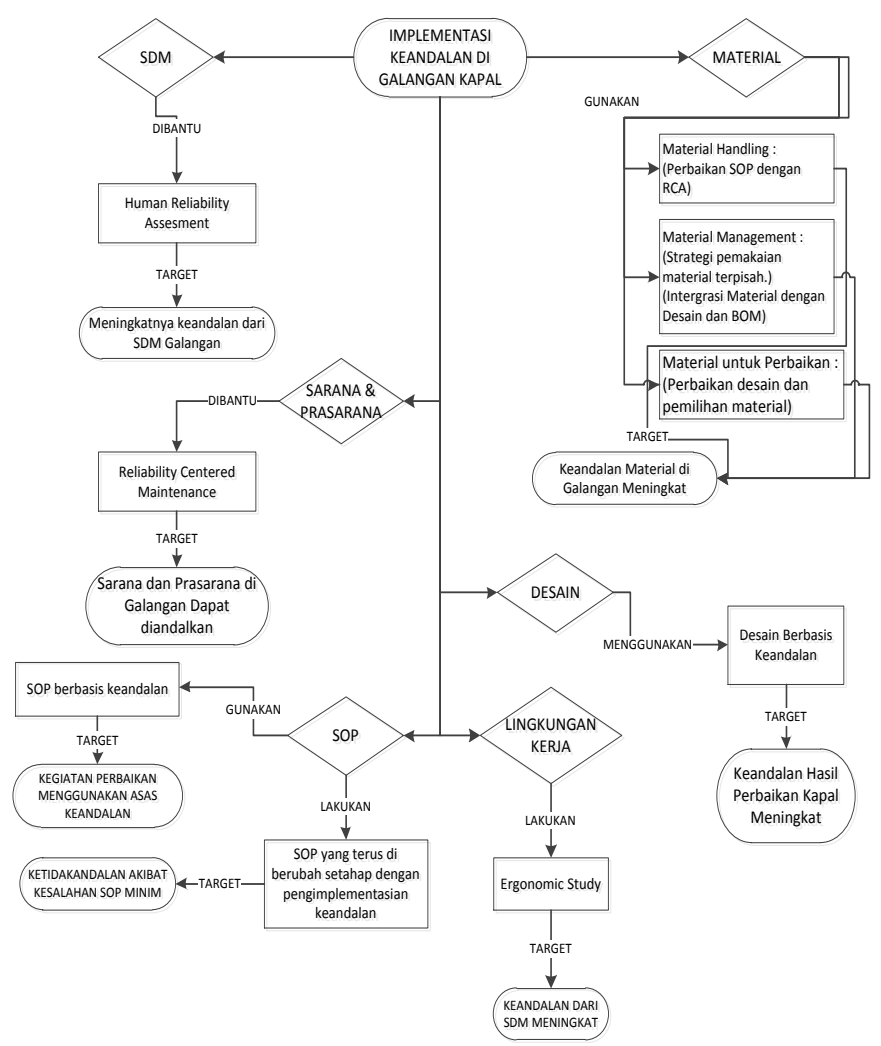

Gambar 8 Teknik \& Alur Implementasi Beserta Target 


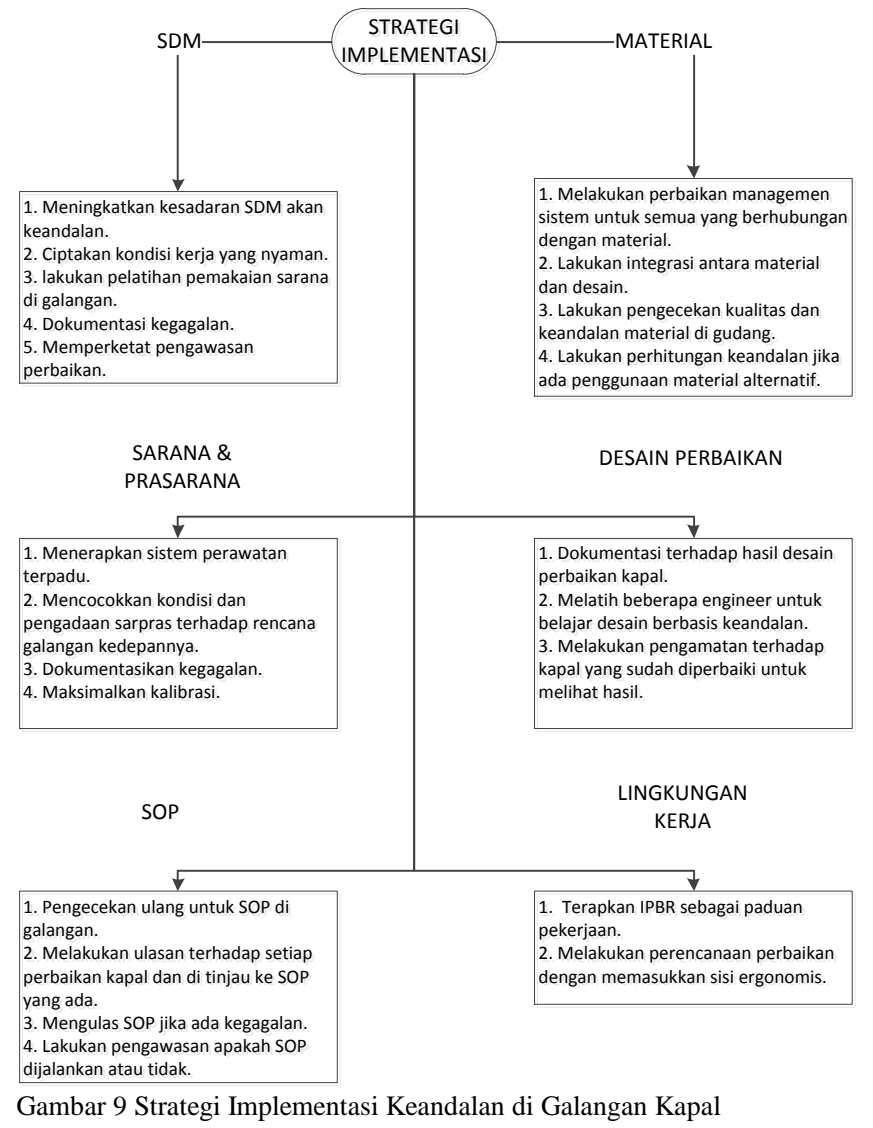

\section{KESIMPULAN}

Kesimpulan-kesimpulan dalam penelitian ini dibuat berdasarkan rumusan-rumusan masalah dan hipotesis yang telah dibuat pada Bab I adalah:

1) Aktivitas perbaikan kapal yang berhubungan dengan keandalan ada dua yaitu; proses perbaikan dan hasil perbaikan. Dalam konteks keandalan, keduanya tidak dapat dikatakan andal. Karena implementasi dan penggunaan keandalan masih minim dilakukan. Keandalan pada perbaikan kapal adalah Probabilitas keberhasilan sebuah galangan untuk memperbaiki kapal sesuai dengan permintaan owner kapal dalam waktu dan kondisi pakai yang ditentukan.

2) Kondisi keandalan pada perbaikan kapal di galangan kapal saat ini dapat diperbaiki dengan menggunakan pendekatan implementasi keandalan berupa reliability analysis. Yaitu teknik pendekatan berbasis kasus yang digunakan untuk menyelidiki akar penyebab masalah pada proses dan hasil perbaikan kapal di galangan kapal.

3) Berdasarkan studi implementasi perbaikan kapal berbasis keandalan, Reliability analysis dilakukan dengan tahap:

1. Melakukan analisa berita acara kerusakan yang dikeluarkan oleh owner untuk memastikan bahwa sumber permasalahan kerusakan karena ketidakandalan pada proses perbaikan kapal digalangan bukan karena karena faktor operasi kapal.

2. Melakukan identifikasi pada faktor SDM di galangan untuk mencari penyebab ketidakandalan, dengan parameter pemeriksaan:

\section{i. Skill Requirement dari SDM.}

ii. Ergonomi SDM pengerjaan pada perbaikan kapal.

iii. Terjadinya alterasi yang disebabkan SDM.

3. Melakukan identifikasi pada faktor Material di galangan untuk mencari penyebab ketidakandalan, dengan paramenter pemeriksaan:

i. Kualitas material pengganti tidak memenuhi.

ii.Spec Requirement material pengganti tidak memenuhi.

iii. Kecocokan material penganti dengan material yang rusak tidak memenuhi.

4. Melakukan identifikasi pada faktor Sarana \& Prasarana di galangan untuk mencari penyebab ketidakandalan, dengan parameter pemeriksaan:

i. Requirement mesin yang digunakan pada perbaikan kapal.

ii.Akurasi mesin yang digunakan pada perbaikan kapal.

iii. Maintenance mesin yang dilakukan pada galangan.

5. Melakukan identifikasi pada faktor SOP di galangan untuk mencari penyebab ketidakandalan, dengan parameter pemeriksaan:

i. Ada atau tidak ada nya SOP perbaikan kapal.

ii.Yard Quality Standard.

iii. Safety regulation dalam bentuk Identifikasi Penilaian Bahaya dan Resiko.

6. Melakukan identifikasi pada faktor Desain dan Dokumen perbaikan kapal di galangan untuk mencari penyebab keridakandalan, dengan parameter pemeriksaan:

i. Kecocokan desain dengan hasil pengerjaan.

ii.Desain kapal yang salah sehingga menyebabkan ketidakandalan.

7. Melakukan identifikasi pada faktor Kondisi Lapangan di galangan untuk mencari penyebab ketidakandalan, dengan parameter pemeriksaan:

i. Nilai ergonomi perlengkapan untuk perbaikan kapal.

ii.Kondisi lapangan ketika melakukan perbaikan kapal.a

8. Melakukan corrective action dan mitigasi untuk mencegah kerusakan terjadi kembali dengan mempertimbangkan faktor yang ditemukan.

9. Apabila model identifikasi umum tidak dapat menemukan penyebab permasalahannya, maka dilakukanlah investigasi khusus. 
DAFTAR PUSTAKA

[1] O'Connor, P. D., \& Kleyner, A. (2012). Practical Reliability Engineering. Chichester: John Wiley \& Sons, Ltd.

[2] Scutti, J. J., \& J., M. W. (2001). Root-Cause Analysis. In A. International, Introduction to Failure Analysis and Prevention (pp. 710). Ohio: ASM International.

[3] Scutti, J. J., \& McBrine, W. J. (2001). Concept of Failure Analysis and Prevention. In A. International, Introduction to Failure Analysis and Prevention (pp. 2-6). Ohio: ASM International.

[4] Sondalini, M. (2007). Bill Masters Reliability and Maintenance Management. Travel 'the Journey' to Reliability and Maintenance Management Mastery. Rossmoyne, WA, Australia: Lifetime Reliability Solutions Global (LRS COnsultant Global).

[5] Kamus Besar Bahasa Indonesia Dalam Jaringan, Diakses Desember 2015 19.33, www.kbbi.web.id 